\title{
Trilhas ecológicas de Cerro Corá (RN)
}

\section{Clébia Bezerra da Silva*, Ednaja Faustino Silva de Moura*, Ricardo Farias do Amaral*}

*Universidade Federal do Rio Grande do Norte, Currais Novos, RN, Brasil.

E-mails: clebia@ufrnet.br, ednajaturismoufrn@gmail.com, projeto_corais@yahoo.com.br

Cerro Corá/RN está localizado a $180 \mathrm{~km}$ de distância de Natal/RN. Dentre seus recursos turísticos, destacam-se os naturais, como a trilha para a nascente do rio Potengi e a do Vale Vulcânico. Essa tem sua origem devido a um vulcão extinto a 25 milhões de anos. No local podem ser encontrados vários tipos de rochas, como basalto. As caminhadas em trilhas ecológicas integram o contato humano com o meio ambiente, tendo como premissa o respeito e a sensibilização dos praticantes em relação à conservação do meio ambiente, onde está pautada a contemplação da paisagem, bem como da fauna e da flora local, dentre outras atividades que permitam o contato com a natureza. Neste sentido o presente trabalho, desenvolvido como parte das ações do projeto integrado Caminhos do Presente, tem por objetivo fazer o levantamento do potencial das trilhas ecológicas de Cerro Corá. Os dados preliminares mostram que a trilhas para a nascente do rio potencia tem grau de dificuldade médio, já a do Vale Vulcânico o grau é difícil, necessitando de bom preparo físico do trilheiro e tem duração de uma hora e meio, tendo duas possibilidades de circuito. Assim, pode-se observar que o município de Cerro Corá apresenta trilhas ecológicas com potencial para o desenvolvimento do turismo tendo a natureza como motivação, mas ainda são necessários investimento para aproveitar todo o potencial delas bem como, dar mais segurança ao visitantes.

PALAVRAS-CHAVE: Trilhas Interpretativas; Educação Ambiental; Vale Vulcânico; Indicadores de Atratividade. 